\begin{tabular}{l|l}
\hline Cotaice & e-ISSN: 2655-9404 \\
Vol. 01 No. 1, Juni 2018 & DOI: $10.20473 /$ ntr.v1i1.9104 \\
\hline
\end{tabular}

Article history: Submitted 1 May 2018; Accepted 15 May 2018; Available online 1 June 2018.

\title{
Eksistensi Doktrin "Piercing The Corporate Veil" Atas Pelaksanaan Sentralisasi Procurement Anak Perusahaan oleh Induk Perusahaan
}

\author{
Titik Tri Sulistyawati \\ titik3s@gmail.com \\ Universitas Airlangga
}

\begin{abstract}
This study aims to examine the law principle which regulate the law principle of "Piercing The Corporate Veil" as referred to Act number 40 years 2007 concerning to limited company in relation to the liability of Parent/Holding Company as the shareholder on the implementation of the centralization of procurement policy from Subsidiary. This legal research is a normative legal research using statute approach and conceptual approach. The technique of collecting legal materials related to this legal research is by library research (study document) with the card system and supported also by the use of snow ball method then analyzed by using the method of interpretation, that is systematic interpretation and grammatical interpretation. The Company Law treats Subsidiary as a separate legal entity from Parent/Holding Company. As an independent legal entity, the management of rights and obligations lies on the authority of each company's organs. The separation of authority leads to the limited liability of the Parent/Holding Company as the majority shareholder of the Subsidiary becomes unlimited to shareholders if there is a breakthrough of Piercing The Corporate Veil principle, due to the "breach of duty" of the Parent/Holding Company. However, Parent/Holding Company's interference with the Subsidiary's management and business activity should be undertaken with respect to the Subsidiary's independency and limited liability of the two entities.
\end{abstract}

Keywords: 'Piercing The Corporate Veil'principle; breach of duty.

\begin{abstract}
Abstrak
Penelitian ini bertujuan untuk menganalisa asas hukum yang mengatur tentang prinsip "Piercing The Corporate Veil" berdasarkan Undang-Undang Nomor 40 Tahun 2007 tentang Perseroan Terbatas berkaitan dengan tanggung jawab Induk Perusahaan sebagai pemegang saham atas pelaksanaan sentralisasi kebijakan procurement dari Anak Perusahaan. Penelitian hukum ini merupakan penelitian hukum normatif dengan menggunakan pendekatan perundang-undangan (statute approach) dan pendekatan konseptual (conseptual approach). Teknik pengumpulan bahan hukum yang berkaitan dengan penulisan hukum ini adalah dengan metode telaah kepustakaan (study document) dengan sistem kartu (card system) dan didukung pula dengan penggunaan metode bola salju (snow ball) selanjutnya dianalisis dengan menggunakan metode interpretasi atau penafsiran, yaitu interpretasi sistematis dan interpretasi gramatikal. Hukum Perseroan memperlakukan Anak Perusahaan sebagai suatu entitas hukum yang terpisah dari Induk Perusahaan. Sebagai badan hukum mandiri, pengurusan hak dan kewajiban terletak pada kewenangan masing-masing organ perseroan. Pemisahan kewenangan itu berujung pada prinsip tanggung jawab terbatas Induk Perusahaan sebagai pemegang saham dari Anak Perusahaan dan menjadi tidak terbatas bagi pemegang saham apabila terdapat penerobosan prinsip "Piercing The Corporate Veill", salah satunya akibat "breach of duty" dari Induk Perusahaan. Namun campur tangan Induk Perusahaan terhadap pengusahaan bisnis dan managemen Anak Perusahaan hendaknya dilakukan dengan menghormati prinsip kemandirian Anak Perusahaan dalam rangka pembatasan tanggung jawab diantara keduanya.
\end{abstract}

Kata Kunci: Prinsip 'Piercing The Corporate Veil'; breach of duty. 


\section{Pendahuluan}

Perusahaan merupakan salah satu sendi utama dalam kehidupan masyarakat modern dan sebagai salah satu pelaku ekonomi, Perusahaan tidak akan berdiri dan melakukan aktivitasnya tanpa adanya kehidupan sosial kemasyarakatan. Perusahaan selalu berada di tengah masyarakat dan hanya dapat hidup, tumbuh dan berkembang apabila memperoleh dukungan dari masyarakat. Masyarakat sebagai konsumen menjadi sasaran bagi Perusahaan untuk mendistribusikan produk maupun jasa yang dihasilkannya. Sebaliknya masyarakat juga dapat berkedudukan sebagai pemasok utama dari kebutuhan Perusahaan. Hubungan timbal balik ini menjadi simbiosis mutualisme. Dengan demikian, masyarakat dalam Perusahaan berada pada dua sisi yang saling membutuhkan dan melengkapi, yaitu ketika masyarakat sebagai konsumen membutuhkan produk maupun jasa yang dihasilkan oleh Perusahaan dan ketika masyarakat sebagai pemasok dibutuhkan Perusahaan untuk menunjang proses produksinya.

Keberadaan Perusahaan di tengah masyarakat tidak dapat dipandang sebelah mata karena peranan pentingnya dalam perputaran roda perekonomian dan perkembangan pembangunan melalui kontribusinya yang tidak kecil sebagai sumber pendapatan Negara, utamanya dari sektor Pajak. Dalam hukum Perusahaan, bentuk badan usaha yang paling disorot adalah Perseroan Terbatas (PT) dan merupakan bentuk badan usaha yang paling sering digunakan didalam praktik.

Dalam perundangan di Indonesia, cikal bakal dari terbentuknya Perusahaan yang paling sederhana adalah persekutuan perdata (maatschap) sebagaimana diatur dalam ketentuan Pasal 1618 sampai dengan Pasal 1665 Burgerlijk Wetboek (BW)/Kitab Undang-Undang Hukum Perdata (KUH Perdata), yang kemudian berkembang selanjutnya adalah Firma, Commanditaire Venootschap (CV) dan Naamloze Vennootschap (company limited by shares) yang disingkat dengan NV, yang merupakan nama dari PT di masa lalu. Didalam perkembangan Perusahaan ini tidak terlepas dari Perjanjian sebagai dasar pembentukannya. Ketiganya diatur dalam Wetboek Van Koophandel (WvK)/Kitab Undang-Undang Hukum Dagang (KUHD). Khusus pada pengaturan mengenai PT terdapat pada ketentuan Pasal 
36 sampai dengan pasal 56 Buku Pertama, Titel Ketiga, Bagian Ketiga tentang Perseroan Terbatas. Pemberlakuan pengaturan tentang PT didalam KUHD ini merupakan Lex Specialis atas pengaturan bentuk-bentuk perusahaan persekutuan (maatschap partnership) yang terdapat didalam Burgerlijk Wetboek (BW)/Kitab Undang-Undang Hukum Perdata (KUH Perdata) sebagaimana disebutkan dalam ketentuan Pasal 1 KUHD : “Kitab Undang-Undang Hukum Perdata berlaku juga bagi hal-hal yang diatur dalam Kitab Undang-Undang ini, sekedar didalam Kitab Undang-Undang ini tidak diatur secara khusus menyimpang."

Perkembangan berikutnya pengaturan mengenai PT ini kemudian dilakukan dengan pembentukan Undang-Undang Nomor 1 Tahun 1995 tentang Perseroan Terbatas yang didalam ketentuan Pasal 128 ayat 1-nya menyatakan tidak berlakunya pengaturan ketentuan PT dalam KUHD oleh karena dinilai sudah tidak dapat lagi mengikuti dan memenuhi kebutuhan perkembangan perekonomian dan dunia usaha. Pengaturan ketentuan PT dalam UU Nomor 1 Tahun 1995 untuk kemudian dilakukan perubahan dengan Undang-Undang Nomor 40 Tahun 2007 tentang Perseroan Terbatas untuk memenuhi kebutuhan masyarakat dan mengakomodir perkembangan hukum di Indonesia.

Pada masa sekarang, banyak PT yang memanfaatkan prinsip limited liability atau pertanggungjawaban terbatas dengan cara mendirikan Anak Perusahaan (Subsidiary) untuk menjalankan bisnis dari Induk Perusahaan (Parent Company) dan dapat dijumpai satu Perseroan Grup (Group Company) terdiri atas sejumlah PT sebagai Anak Perusahaan (Subsidiary). Perseroan Holding (Parent Company) kemungkinan besar tidak aktif melakukan kegiatan bisnis atau perdagangan dan hanya menanamkan saham dalam berbagai PT sebagai Anak Perusahaan (Subsidiary) dan kemudian Anak Perusahaan (Subsidiary) yang melaksanakan kegiatan usaha. Dan kemudian selanjutnya Anak Perusahaan (Subsidiary) itu pun mendirikan Anak Perusahaan (Subsidiary) lagi. Demikian seterusnya, sehingga Perusahaan Holding memiliki banyak Anak Perusahaan (Subsidiary). Dalam kondisi seperti ini terkadang tidak terdapat pemisahan (separate) dan perbedaan (distinction) mengenai eksistensi ekonomi dan aset, karyawan maupun pemisahan 
bisnis dan Direksi antara Perseroan Holding (Holding/Parent Company) dengan Anak Perusahaan (Subsidiary).

Didalam menunjang proses produksi dari Anak Perusahaan (Subsidiary) yang ada, Induk Perusahaan (Parent Company) mempunyai kebijakan non konvensional yang bahkan mungkin dapat dikatakan sebagai suatu modifikasi hukum yang muncul untuk kepentingan dan perkembangan bisnis suatu Perseroan Grup (Group Company), salah satunya dengan menerapkan kebijakan sentralisasi pengadaan barang dan/atau jasa (procurement) dari Anak Perusahaan (Subsidiary) untuk dilaksanakan oleh Induk Perusahaan (Parent/Holding Company) yang dinyatakan melalui mekanisme Rapat Umum Pemegang Saham (RUPS). Hal ini dilakukan bertujuan guna mendapatkan harga dan kualitas barang dan/atau jasa yang terbaik melalui perencanaan prosedural, negosiasi yang optimal dan koordinasi yang terarah. Proses procurement ini dilakukan oleh Induk Perusahaan (Parent/Holding Company) dengan mengikuti sistem dan prosedur dari Induk Perusahaan (Parent/Holding Company), dimana Anak Perusahaan (Subsidiary) menyatakan penundukan diri didalam Perjanjian yang mengikat keduanya yang mengatur teknis pelaksanaan procurement.

Berdasarkan latar belakang tersebut diatas, dapat dirumuskan permasalahan terdapatnya resiko hukum perluasan pertanggungjawaban pada Induk Perusahaan (Parent/Holding Company) akibat penerobosan asas hukum Corporate Separate Legal Personality melalui pelaksanaan sentralisasi procurement dari Anak Perusahaan (Subsidiary) oleh Induk Perusahaan (Parent/Holding Company) dimana hal ini dapat dikatakan sebagai suatu bentuk campur tangan dari Induk Perusahaan (Parent/Holding Company) kedalam managemen Anak Perusahaan (Subsidiary).

\section{Metode Penelitian}

Penelitian ini merupakan penelitian hukum normatif, dimana dilakukan penelusuran terhadap permasalahan yang telah dirumuskan dengan didasarkan pada peraturan perundang-undangan yang berlaku dan bertujuan untuk menemukan aturan hukum, prinsip-prinsip hukum, maupun doktrin-doktrin hukum dengan menggunakan hukum normatif dan melakukan telaah mengenai konsep-konsep 
hukum berdasarkan pendapat para ahli hukum untuk meningkatkan daya interpretasi guna menjawab isu hukum yang dihadapi. ${ }^{1}$

Pendekatan yang digunakan adalah pendekatan peraturan perundanganundangan (statute approach) dan pendekatan konsep (conseptual approach). Pendekatan perundang-undangan merupakan pendekatan yang dilakukan dengan menelaah semua undang-undang dan regulasi yang bersangkut paut dengan isu hukum yang ditangani. ${ }^{2}$ Pendekatan ini dilakukan untuk memecahkan rumusan masalah yang ada dengan menunjuk pada prinsip-prinsip hukum yang relevan.

Selain pendekatan peraturan perundang-undangan (statute approach), penelitian ini juga menggunakan pendekatan konseptual (conceptual approach). Pendekatan ini beranjak dari pandangan-pandangan dan doktrin-doktrin yang berkembang didalam ilmu hukum. ${ }^{3}$ Dengan mempelajari dan melakukan pemahaman atas pandangan-pandangan dan doktrin-doktrin tersebut, maka akan dapat ditemukan ide-ide yang melahirkan pengertian-pengertian hukum, konsepkonsep hukum dan asas-asas hukum yang relevan dengan isu yang dihadapi yang dapat membangun suatu argumentasi hukum dalam memecahkan isu yang dihadapi. Kedua pendekatan tersebut diharapkan dapat memberikan jawaban terhadap rumusan masalah yang akan dibahas.

Bahan hukum yang dipergunakan adalah terdiri bahan hukum primer berupa peraturan perundangan-undangan, yaitu Burgerlijk Wetboek (BW)/Kitab UndangUndang Hukum Perdata (KUH Perdata), Wetboek Van Koophandel (WvK)/Kitab Undang-Undang Hukum Dagang (KUHD) dan Undang-Undang Nomor 40 tahun 2007 tentang Perseroan Terbatas. Sedangkan bahan hukum sekunder yang digunakan adalah literatur-literatur ilmu hukum, yaitu buku-buku hukum disamping itu juga kamus-kamus hukum yang berkaitan dengan isu yang dihadapi. Kesemuanya dikumpulkan melalui metode telaah kepustakaan (study document) dengan sistem kartu (card system) dan didukung pula dengan penggunaan metode bola salju (snow

\footnotetext{
${ }^{1}$ Peter Mahmud Marzuki, Penelitian Hukum (Kencana Prenada Media Grup 2009).[35].

${ }^{2}$ ibid.[133].

${ }^{3}$ ibid.[135].
} 
ball) yakni dengan cara seluruh bahan hukum dikumpulkan, kemudian dipelajari dan dilakukan pengolahan untuk memilih bahan-bahan yang saling berkaitan antara bahan hukum primer dan bahan hukum sekunder selanjutnya dianalisis dengan menggunakan metode interpretasi atau penafsiran untuk mengetahui makna undangundang, dengan menggunakan interpretasi gramatikal dan interpretasi sistematis.

\section{Hakikat Perseroan Terbatas (PT) sebagai Badan Hukum.}

Dalam ketentuan Pasal 1 angka 1 Undang-Undang Nomor 40 Tahun 2007 tentang Perseroan Terbatas (UUPT) dinyatakan bahwa :

"Perseroan Terbatas, yang selanjutnya disebut Perseroan, adalah badan hukum yang merupakan persekutuan modal, didirikan berdasarkan Perjanjian, melakukan kegiatan usaha dengan modal dasar yang seluruhnya terbagi dalam saham dan memenuhi persyaratan yang ditetapkan dalam Undang-Undang ini serta peraturan pelaksanaannya".

Badan Usaha dikatakan berbadan hukum apabila memenuhi syarat-syarat sebagai badan hukum, antara lain: adanya kekayaan yang terpisah antara badan hukum dengan organ badan hukum, adanya tujuan tertentu yang terlepas dari tujuan organ badan hukum yang terdapat dalam Anggaran Dasarnya, adanya kepentingan tertentu yang terlepas dari kepentingan organ badan hukum dan adanya organisasi yang teratur dengan pengurus yang mewakili badan hukum dalam bertindak. ${ }^{4}$

Keberadaan status badan hukum PT selain memenuhi syarat tersebut diatas, baru diperoleh setelah memperoleh pengesahan dari Pejabat yang berwenang sebagaimana disebutkan dalam ketentuan Pasal 7 ayat 4 UUPT. Dan setelah PT mendapatkan badan hukum, maka ia merupakan subyek hukum seperti halnya manusia (artificial legal person) yang memiliki hak dan kewajiban dalam melakukan perbuatan hukum untuk mencapai tujuannya. Dengan status badan hukum ini, hukum memberikan kedudukan PT sebagai "persona standi in judicio" dengan memperlakukan pemilik atau pemegang saham dan pengurus atau Direksi terpisah dari PT itu sendiri, artinya PT sebagai individu yang berdiri

${ }^{4}$ Tuti Rastuti, Seluk Beluk Perusahaan Dan Hukum Perusahaan (PT Refika Aditama 2015).[37]. 
sendiri, sehingga semua perbuatan hukum yang dilakukan untuk dan atas nama PT adalah menjadi tanggung jawab PT itu sendiri.

Sehingga apabila disimpulkan, ciri-ciri PT adalah Pemegang Saham tidak bertanggung jawab secara pribadi atas perikatan yang dibuat atas nama Perseroan, Pemegang Saham tidak bertanggung jawab atas kerugian Perseroan melebihi nilai saham yang telah diambilnya, dan tidak meliputi harta kekayaan pribadinya (prinsip limited liability) dan semua tindakan organ PT seperti Direksi, Dewan Komisaris menjadi tanggung jawab PT. ${ }^{5}$

\section{Organ Perseroan Terbatas}

Adanya organisasi Perusahaan merupakan salah satu syarat untuk dapat dikatakan suatu badan usaha sebagai badan hukum, yang mana dalam organisasi tersebut akan ditentukan pembagian tugas, fungsi, kewajiban dan tanggung jawab dari masing-masing organ yang terpola hubungan hukum dan koordinasinya.

PT didalam menjalankan kegiatan usahanya dikelola oleh Organ Perusahaan yang merupakan lembaga tersendiri yang terdiri atas orang-orang yang menjalankan Perusahaan dan terpisah kedudukannya. Menurut ketentuan Pasal 1 angka 2 UUPT, Organ PT adalah terdiri dari Direksi, Dewan Komisaris dan Rapat Umum Pemegang Saham. Kedudukan ketiga organ PT ini adalah sejajar (neben) dan bukan yang satu membawahi yang lain (untergeordnet) dimana masing-masing mempunyai tugas dan kewenangannya sendiri menurut dan dalam batas yang diatur dalam Anggaran Dasar PT dan UUPT.

Direksi sebagai salah satu organ PT mempunyai 2 (dua) fungsi utama, ${ }^{6}$ antara lain fungsi manajemen untuk memimpin perusahaan dan fungsi representasi untuk mewakili Perusahaan didalam dan diluar Pengadilan yang menyebabkan Perseroan sebagai badan hukum akan terikat dengan transaksi atau kontrak-kontrak yang dibuat oleh Direksi untuk dan atas nama serta kepentingan perseroan. Didalam menjalankan dan melaksanakan "pengurusan" sehari-hari (beheer, administration or management)

\footnotetext{
${ }^{5}$ Zaeni Asyhadie dan Budi Sutrisno, Hukum Perusahaan Dan Kepailitan (Erlangga 2012).[115].
}

${ }^{6}$ Munir Fuady, Doktrin-Doktrin Modern Dalam Corporate Law (PT Citra Aditya Bakt 2014).[30]. 
adalah meliputi tugas atau fungsi melaksanakan kekuasaan pengadministrasian dan pemeliharaan harta kekayaan perseroan. Dengan kata lain, melaksanakan pengelolaan atau menangani bisnis perseroan dalam arti sesuai dengan maksud dan tujuan Perseroan serta kegiatan Perseroan didalam batas-batas kekuasaan atau kapasitas yang diberikan Undang-Undang dan Anggaran Dasar kepadanya. ${ }^{7}$

Dewan Komisaris sebagai salah satu organ PT lainnya mempunyai tugas dan fungsi diantaranya melakukan pengawasan terhadap kebijaksanaan pengurusan Perseroan yang dilakukan Direksi dan jalannya pengurusan perseroan pada umumnya serta memberikan nasehat kepada Direksi yang secara yuridis bersifat "rekomendasi", berupa pendapat atau pertimbangan yang layak dan tepat kepada Direksi dan tidak bersifat mengikat. Bahkan Dewan Komisaris dapat juga menyampaikan ajaran yang baik maupun petunjuk, peringatan atau teguran yang baik. $^{8}$

Rapat Umum Pemegang Saham sebagai organ tertinggi PT memberikan kewenangan yang tidak diberikan kepada Direksi dan/atau Dewan Komisaris. Melalui RUPS inilah para pemegang saham sebagai pemilik (eigenaar, owner) Perseroan melakukan kontrol terhadap kepengurusan yang dilakukan Direksi maupun terhadap kekayaan serta kebijakan kepengurusan yang dijalankan oleh Perseroan. ${ }^{9}$

\section{Asas Hukum Corporate Separate Legal Personality dalam UUPT.}

Asas hukum Corporate Separate Legal Personality merupakan asas yang esensinya bahwa suatu perusahaan, dalam hal ini PT mempunyai personalitas atau kepribadian yang berbeda dari yang menciptakannya. ${ }^{10}$ Asas ini berangkat dari suatu doktrin dasar PT dimana PT adalah suatu perusahaan yang merupakan suatu kesatuan hukum yang terpisah dari subjek hukum pribadi yang menjadi pendiri atau pemegang saham dari Perusahaan tersebut. Terdapat suatu tabir pemisah (veil) antara Perusahaan sebagai suatu legal entity dengan para pemegang saham dari Perusahaan tersabut.

\footnotetext{
${ }^{7}$ M. Yahya Harahap, Hukum Perseroan Terbatas (Sinar Grafika 2015).[346].

${ }^{8}$ ibid. [439].

${ }^{9}$ ibid.[306].

${ }^{10}$ Tuti Rastuti (n 4).Op.Cit.[133].
} 
Asas ini terdapat dalam ketentuan Pasal 3 ayat 1 UUPT yang menentukan bahwa pemegang saham perusahaan tidak bertanggung jawab secara pribadi atas perikatan yang dibuat atas nama perusahaan dan tidak bertanggung jawab atas kerugian Perusahaan melebihi nilai saham yang dimilikinya.

Dalam kaitannya dengan permasalahan ini, Asas Hukum Corporate Separate Legal Personality menyatakan dengan tegas bahwa PT merupakan suatu kesatuan hukum yang terpisah (separate legal entity) dari subjek hukum pribadi yang menjadi pendiri atau pemegang saham, sehingga tanggung jawab pemegang saham hanya terbatas sebesar nilai sahamnya (limited liability of its shareholders). Saham yang dimiliki oleh pemegang saham sebagai suatu bukti kepemilikan, pada umumnya hanya memberi hak kepada pemegang saham untuk mengeluarkan hak suara dalam RUPS, menerima dividen, menerima aset PT secara proporsional apabila terjadi likuidasi sesuai dengan jumlah saham yang dimiliki, mempunyai hak kontrol tidak langsung atas operasional sehari-hari PT dan atas segala kebijakan Direksi. ${ }^{11}$ Akan tetapi terkait hal terakhir ini, pemegang saham tidak memikul tanggung jawab atas pelaksanaan fungsi Direksi. Dengan demikian, semakin banyak saham yang dimiliki oleh pemegang saham (mayoritas), maka akan semakin besar pula kekuasaan kontrol yang dapat dilakukannya atas PT.

Terjadinya pemisahan (separate) dan perbedaan (distinct) antara PT dengan pemilik atau pemegang saham ini dimulai terhitung sejak PT mendapatkan keputusan pengesahan sebagai Badan Hukum dari Menteri Hukum dan Hak Asasi Manusia sebagaimana disebutkan dalam ketentuan Pasal 9 ayat 1 UUPT. $^{12}$

Tanggung jawab Induk Perusahaan (Parent/Holding Company) dan Anak Perusahaan (Subsidiary) dalam Perseroan Grup (Group Company).

Didalam Undang-Undang Nomor 40 tahun 2007 tentang Perseroan Terbatas tidak dapat menjelaskan secara tegas dan eksplisit mengatur ketentuan khusus mengenai Perseroan Grup (Group Company) maupun Perseroan Holding (Parent)

\footnotetext{
${ }^{11}$ M. Yahya Harahap (n 7).Op.Cit.[73].

12 ibid.[72].
} 
Holding Company). Kerangka pengaturan terhadap kedua hal tersebut masih menggunakan pendekatan Perseroan tunggal. Artinya, pengaturan mengenai perseroan yang tergabung dalam konstruksi Perseroan Grup (Group Company) menjadi bagian dari hukum perseroan. ${ }^{13}$ Sehingga dengan demikian, hukum Perseroan akan tetap memperlakukan Anak Perusahaan (Subsidiary) sebagai suatu entitas hukum yang terpisah (separate legal entity) dari Induk Perusahaan (Parent/Holding Company) yang mempunyai hak dan kewajiban yang mandiri sebagai suatu badan hukum dan pengurusannya ada pada kewenangan dan tugas Direksi anak perusahaan, Dewan Komisaris sebagai pengawas dan RUPS sebagai pengontrol terhadap kepengurusan yang dilakukan oleh Direksi maupun terhadap kekayaan serta kebijakan (policy) kepengurusan yang dijalankan oleh managemen perseroan. Kesemuanya itu berujung pada prinsip tanggung jawab terbatas (limited liability) Induk Perusahaan (Parent/ Holding Company) sebagai pemegang saham dari Anak Perusahaan (Subsidiary).

Dari pengaturan ketentuan Pasal 1 angka 1 jo. Pasal 7 ayat 1 UUPT terlihat bahwa UUPT memberikan hak konstitusional bagi orang perseorangan (natuurlijke person) ataupun badan hukum (recht person) untuk mendirikan sebuah perusahaan baru dengan syarat didirikan oleh 2 (dua) orang. Legitimasi atas hak untuk mendirikan perseroan itulah yang menjadikan suatu badan hukum perseroan merasa mendapat pengakuan secara hukum atas lahirnya konstruksi perusahaan grup (Grup Company) di Indonesia. ${ }^{14}$

Perusahaan holding sering juga disebut dengan "Holding Company", "Parent Company" atau "Controlling Company" adalah suatu Perusahaan yang bertujuan untuk memiliki saham dalam 1 (satu) atau lebih perusahaan lain dan/atau mengatur 1 (satu) atau lebih perusahaan lain tersebut. Biasanya (walaupun tidak selamanya), suatu perusahaan holding memiliki banyak perusahaan yang bergerak dalam bidang-bidang bisnis yang sangat berbeda-beda. ${ }^{15}$ 2010).[9].

${ }^{13}$ Sulistyowati, Aspek Hukum Dan Realita Bisnis Perusahaan Grup Di Indonesia (Erlangga ${ }^{14}$ ibid.[21].

${ }^{15}$ Munir Fuady, Hukum Perusahaan Dalam Paradigma Hukum Bisnis (Berdasarkan Undang-Undang Nomor 40 Tahun 2007) (PT Citra Aditya Bakti 2008).[86]. 
Prosedur dalam pembentukan Perusahaan Holding secara umumnya dapat terjadi melalui 3 (tiga) prosedur, yaitu prosedur residu dimana perusahaan asal dipecahpecah sesuai dengan masing-masing sektor usaha, dimana perusahaan yang dipecahpecah tersebut telah menjadi perusahaan yang mandiri. Sementara perusahaan yang tersisa (residu) dari perusahaan asal dikonversi menjadi perusahaan holding, yang juga memegang saham pada perusahaan pecahan tersebut dan perusahaan-perusahaan lainnya apabila ada. ${ }^{16}$ Yang kedua adalah prosedur penuh yang sebaiknya dilakukan apabila sebelumnya tidak terlalu banyak terjadi pemecahan/pemandirian perusahaan, tetapi masing-masing perusahaan dengan kepemilikan yang sama/berhubungan saling terpencar-pencar, tanpa terkonsentrasi dalam suatu perusahaan holding. Dalam hal ini, yang menjadi perusahaan holding bukan sisa dari perusahaan asal (seperti pada prosedur residu), melainkan perusahaan penuh dan mandiri. ${ }^{17}$ Prosedur terakhir adalah prosedur terprogram, dimana hal ini diterapkan apabila pada awal memulai bisnis sudah terpikir untuk membentuk suatu perusahaan holding, sehingga perusahaan yang pertama kali didirikan dalam grupnya adalah perusahaan holding. Kemudian, untuk setiap bisnis yang dilakukan akan dibentuk atau mengakuisisi perusahaan lain, dimana perusahaan holding sebagai pemegang saham akan menggandeng partner bisnis untuk bersama-sama menjalankan kegiatan usaha. Seiring dengan berkembangnya bisnis perusahaan induk, maka jumlah perusahaan yang baru yang masuk sebagai anak perusahaan akan terus bertambah. ${ }^{18}$

Lebih lanjut untuk dapat menggambarkan hubungan hukum antara Anak Perusahaan (Subsidiary) dengan Induk Perusahaan (Parent/Holding Company) adalah sebagaimana digambarkan dalam "Black's Law Dictionary” mengenai istilah Induk Perusahaan yang sering disebut sebagai "Holding Company" atau "Parent Company” atau "Controlling Company":

A company that usually compines its activities to owning stock in, and supervising management of, other companies. A holding Company usually owns a controlling interesting in the companies whose stock it holds. In order

\footnotetext{
${ }^{16}$ ibid.

${ }^{17}$ ibid. [87].

${ }^{18}$ ibid.[89].
} 
for a corporation to gain the benefits of tax consolidation, including tax free dividencs and the ability to share operating losses, the holding company must own $80 \%$ or more of the voting stock of the corporation. ${ }^{19}$

Unsur yang dapat ditarik dari pengertian tersebut antara lain bahwa Induk Perusahaan memiliki saham di perusahaan lain, dalam hal ini yang dimaksud adalah Anak Perusahaan (Subsidiary), mengawasi pengelolaan Anak Perusahaan (Subsidiary), Induk Perusahaan memiliki daya mengendalikan kepentingan perusahaan yang dimilikinya, tujuan dari Induk Perusahaan adalah untuk mendapatkan dari konsolidasi pajak, termasuk bebas pajak dividen, membagi kerugian biaya operasional dan Induk Perusahaan harus memiliki $80 \%$ atau lebih hak suara atas saham Anak Perusahaan (Subsidiary) yang dimilikinya.

Sedangkan pengertian Anak Perusahaan (Subsidiary) tidak terdapat pada Undang-Undang Nomor 40 tahun 2007 tentang Perseroan Terbatas, akan tetapi dikemukakan pada penjelasan Pasal 29 Undang-Undang Nomor 1 Tahun 1995 tentang Perseroan Terbatas (UUPT 1995) yaitu:

“...yang dimaksud dengan Anak Perusahaan adalah Perseroan yang mempunyai hubungan khusus dengan perseroan lainnya yang terjadi karena:

1) Lebih dari $50 \%$ (lima puluh persen) sahamnya dimiliki oleh induk perusahaannya;

2) Lebih dari $50 \%$ (lima puluh persen) suara dalam RUPS dikuasai oleh induk perusahaannya; dan atau

3) Kontrol atas jalannya perseroan, pengangkatan dan pemberhentian Direksi dan Komisaris sangat dipengaruhi oleh induk perusahaannya".

Dari kedua terminologi mengenai Induk Perusahaan dan Anak Perusahaan tersebut dapat disimpulkan bahwa Bentuk Holding Company memungkinkan perusahaan membangun, mengendalikan, mengelola, mengonsolidasikan, serta mengkoordinasikan aktivitas dalam sebuah lingkungan multibisnis. Oleh karena lebih dari $50 \%$ (lima puluh persen) suara dalam RUPS dikuasai oleh induk perusahaan maka kontrol atas jalannya perseroan, pengangkatan dan pemberhentian Direksi dan Dewan Komisaris di anak perusahaan sangat dipengaruhi oleh induk perusahaannya.

${ }^{19}$ Henry Campbell, Black’s Law Dictionary (Web Publishing CO 1999).[274]. 


\section{Prinsip Piercing The Corporate Veil.}

Teori dalam hukum perusahaan yang disebut dengan teori penyingkapan tirai perusahaan (piercing the corporate veil) disebut juga dengan istilah "lifting the corporate veil" atau "going behind the corporate veil". Penerapan teori ini mempunyai misi utama yaitu untuk mencapai keadilan khususnya bagi pihak ketiga dengan pihak perusahaan yang mempunyai hubungan hukum tertentu.

Secara harfiah, istilah "piercing the corporate veil" berarti mengoyak/ menyingkapi tirai/kerudung perusahaan, sedangkan dalam ilmu hukum perusahaan istilah tersebut sudah merupakan suatu doktrin atau teori yang diartikan sebagai suatu proses untuk membebani tanggung jawab ke pundak orang atau perusahaan lain atas perbuatan hukum yang dilakukan oleh suatu perusahaan pelaku (badan hukum), tanpa melihat pada fakta bahwa perbuatan tersebut sebenarnya dilakukan oleh perseroan pelaku tersebut. ${ }^{20}$

Dalam Black's Law Dictionary, "Piercing The Corporate Veil" adalah "The judicial act of imposing personal liability on otherwise immune corporate officers, directors and shareholders for the corporation's wrongful act." ${ }^{21}$ Dari rumusan pengertian tersebut menunjukkan bahwa "Piercing The Corporate Veil" hanya dapat terjadi dalam hal adanya tindakan atau perbuatan yang salah. Yang menjadi perhatian bahwa dilarang bukan saja melakukan sesuatu yang seharusnya tidak dilakukan atau melakukan sesuatu yang tidak boleh dilakukan, melainkan termasuk juga dalam kategori melakukan tindakan atau perbuatan yang salah. Dengan demikian, terjadinya "Piercing The Corporate Veil" adalah bergantung sepenuhnya kepada kewenangan yang dimiliki dan kewajiban yang dipikul oleh pihak yang hendak dimintakan pertanggungjawaban pribadi tersebut dan kemungkinan penyebab terjadinya pelanggaran terhadap luasnya kewenangan yang dimiliki dan/ atau kewajiban yang dipikul.

Dalam sistem hukum Indonesia prinsip "Piercing The Corporate Veil" ini diakui secara tegas dalam ketentuan Pasal 3 ayat 2 jo. Pasal 7 ayat 6 UUPT, dimana

\footnotetext{
${ }^{20}$ Munir Fuady (n 6).Op.Cit[7].

${ }^{21}$ Henry Campbell (n 19).[1168].
} 
tanggung jawab hukum tidak hanya dapat dimintakan dari perseroan (meskipun berbentuk badan hukum), tetapi juga dapat dimintakan terhadap pemegang sahamnya, antara lain apabila terjadi beberapa kondisi antara lain apabila persyaratan perseroan sebagai badan hukum belum atau tidak terpenuhi, pemegang saham baik langsung maupun tidak langsung dengan itikad buruk memanfaatkan perseroan untuk kepentingan pribadi, pemegang saham terlibat dalam perbuatan melawan hukum yang dilakukan oleh Perseroan, pemegang saham baik langsung maupun tidak langsung secara melawan hukum menggunakan kekayaan Perseroan dan mengakibatkan kekayaan Perseroan menjadi tidak cukup untuk melunasi utang Perseroan; serta apabila pemegang saham perseroan masih kurang dari 2 (dua) orang dalam jangka waktu melebihi 6 (enam) bulan.

Selain dari kondisi-kondisi tersebut, terdapat hal-hal lainnya yang dapat mengakibatkan timbulnya konsekuensi dibebankannya tanggung jawab hukum ke pundak pemegang saham dan penerapan prinsip "Piercing The Corporate Veil" ini dilakukan secara universal, diantaranya karena perusahaan tidak mengikuti formalitas tertentu yang diharuskan oleh hukum bagi suatu perseroan, seperti misalnya tidak tuntasnya formalitas pendirian perusahaan; tidak melakukan rapat, pemilihan Direksi atau Komisaris; tidak melakukan penyetoran modal atau pengisuan saham; pihak pemegang saham terlalu banyak mencampuri urusan perusahaan; pencampuradukan antara urusan perseroan dan urusan pribadi. ${ }^{22}$

Penerapan prinsip "Piercing The Corporate Veil" juga dilakukan terhadap badan-badan hukum yang hanya terpisah secara artificial, dalam arti perusahaan yang sebenarnya dalam kenyataan adalah tunggal (1 business entity), tetapi perusahaan tersebut dibagi kedalam beberapa perseroan secara artificial. Misalnya terdapat beberapa perseroan yang terpisah secara artificial tetapi bisnisnya dilakukan sedemikian rupa sehingga seolah-olah bisnis tersebut dilakukan oleh 1 (satu) unit perusahaan saja. Dengan penerapan prinsip ini maka beban tanggung jawab akan diberikan kepada seluruh perseroan yang saling terkait tersebut. ${ }^{23}$

\footnotetext{
${ }^{22}$ Munir Fuady (n 6).Op.Cit. [10].

${ }^{23}$ ibid.
} 
Penerapan prinsip "Piercing The Corporate Veil" juga diterapkan apabila terdapat hubungan kontraktual antara perusahaan dengan pihak ketiga dengan unsur "keadaan yang tidak lazim" pada aktivitas perusahaan seperti misalnya pihak ketiga diperdaya untuk bertransaksi dengan Perseroan; Perseroan dioperasikan dengan cara yang tidak layak, misalnya terdapat kejadian atau fakta bahwa perusahaan sama sekali tidak membuat untung dan selalu dibuat dalam kekurangan cash flow, semua dana perseroan disedot oleh pemegang saham tanpa memedulikan nasib perseroan. ${ }^{24}$

Penerapan prinsip "Piercing The Corporate Veil" juga diterapkan karena adanya perbuatan hukum melawan hukum (tort) atau tindak pidana, sekalipun hal tersebut dilakukan oleh perseroan itu sendiri dan karena adanya perbuatan melawan hukum bidang perdata (onrechmatigedaad). ${ }^{25}$

Dalam hubungan antara holding company (parent/holding company) dengan anak perusahaan (subsidiary), penerapan prinsip "Piercing The Corporate Veil" dapat dilakukan apabila anak perusahaan (subsidiary) hanya berfungsi sebagai "instrumen" mencari untung pribadi dari pemegang sahamnya (perusahaan holding atau pemegang saham individu memegang dominasi dan memperalat perseroan untuk kepentingan dirinya). Dalam hal ini menurut ilmu hukum dikenal apa yang disebut dengan doktrin instrumental (instrumentality doctrine), dimana dalam hal ini, perseroan dikatakan sebagai "alter ego" (instrumentality, dummy atau agent) atau diri lain (other self), yakni menjadi diri dari pemegang saham yag memiliki dominasi itu. Maka, pihak yang bertanggung jawab bukan hanya badan hukum yang melakukan perbuatan hukum yang bersangkutan, melainkan juga pemegang saham (perusahaan holding atau pemegang saham individu) ikut bertanggung jawab secara hukum, yakni apabila terdapat salah satu dari unsurunsur: Express Agency; Estoppel; Direct tort; atau adanya 3 (tiga) unsur antara lain: pengontrolan anak perusahaan (subsidiary) oleh perusahaan holding (parent) holding company), penggunaan kontrol oleh perusahaan holding (parent/holding company) untuk melakukan penipuan, ketidakjujuran, atau tindakan tidak fair
24 ibid.
25 ibid. 
lainnya maupun terdapatnya kerugian sebagai akibat dari breach of duty dari perusahaan holding (parent/holding company). ${ }^{26}$

Beberapa fakta lainnya yang dapat dijumpai didalam praktek yang dapat menyebabkan pemberlakuan prinsip "Piercing The Corporate Veil" dalam sebuah perusahaan holding, antara lain: tidak ada pemilihan Direktur dan Komisaris dalam RUPS, holding company dan anak perusahaan mempunyai pengurus, komisaris atau pegawai yang sama, holding company menggunakan aset perusahaan demi kepentingan pribadi, holding company membiayai anak perusahaannya dalam jumlah besar, holding company memiliki seluruh atau hampir seluruh saham anak perusahaan, anak perusahaan mempunyai modal yang sangat kecil dibandingkan dengan bisnis yang dijalankannya, kegiatan operasi sehari-hari dari bisnis holding company tidak terpisah dari anak perusahaannya, anak perusahaan tidak akan menjalankan usahanya apabila tidak mendapat perintah atau pekerjaan dari holding company atau anak perusahaan mempunyai bisnis hanya dengan perusahaan holding, holding company membiayai gaji, upah karyawan anak perusahaan dan membiayai pengeluaran (expenses) lainnya dari anak perusahaan, anak perusahaan bertindak untuk kepentingan holding company, pihak eksekutif anak perusahaan lebih memperhatikan kepentingan Holding Company daripada kepentingan anak perusahaan. ${ }^{27}$

\section{Prinsip Piercing The Corporate Veil dalam Perseroan Grup (Group Company) dalam pelaksanaan Procurement dari Anak Perusahaan (Subsidiary) oleh Induk Perusahaan (Parent/Holding Company).}

Status hukum dari Anak Perusahaan (Subsidiary) adalah sebagai suatu entitas hukum yang terpisah (separate legal entity) dari Induk Perusahaan (Parent/Holding Company). Anak perusahaan mempunyai hak dan kewajiban yang mandiri sebagai suatu badan hukum dan pengurusannya ada pada kewenangan yang terpisah yang dimiliki oleh masing-masing organ perseroannya sebagaimana diatur dalam UUPT

\footnotetext{
${ }^{26}$ ibid.

${ }^{27}$ Robert Prayoko, Doktrin Business Judgement Rule Aplikasinya Dalam Hukum Perusahaan Modern (Graha Ilmu 2015).[170].
} 
dan Anggaran Dasar Perseroan, dimana Direksi anak perusahaan melakukan pengurusan perseroan sehari-hari(day to day operation) dengan itikad baik dan penuh tanggung jawab termasuk didalamnya adalah managemen perseroan dan membuat keputusan bisnis (business decision), sedangkan Dewan Komisaris anak perusahaan adalah sebagai pengawas dan RUPS anak perusahaan sebagai pengontrol terhadap kepengurusan yang dilakukan oleh Direksi anak perusahaan maupun terhadap kekayaan serta kebijakan (policy) kepengurusan yang dijalankan oleh managemen perseroan. Pemegang saham dari anak perusahaan hanya mempunyai hak kontrol tidak langsung atas operasional sehari-hari perseroan dan atas kebijakan Direksi. Lebih khusus terkait peran pemegang saham adalah hanya mengarahkan garis-garis kebijakan perseroan melalui mekanisme Rapat Umum Pemegang Saham dan tidak ikut memikul tanggung jawab atas pelaksanaan fungsi Direksi.

Keterlibatan perusahaan holding dalam anak perusahaan sebagai pemegang saham terhadap bisnis anak perusahaan dapat dimungkinkan untuk dilakukan melalui penempatan orang-orang kepercayaan (nominee)/wakilnya sebagai Direksi dan Dewan Komisaris anak perusahaan, sehingga secara langsung perusahaan holding dapat "mendikte" jalannya bisnis anak perusahaan maupun melalui hubungan kontraktual (sejauh tidak bertentangan dengan anggaran dasar perseroan).

Dalam hubungannya dengan pelaksanaan procurement dari Anak Perusahaan (Subsidiary) untuk dilaksanakan oleh Induk Perusahaan (Parent/Holding Company), keterlibatan Induk Perusahaan (Parent/Holding Company) adalah dengan melalui mekanisme RUPS pada anak perusahaan, yaitu menentukan kebijakan non konvensional sebagai bentuk campur tangan Induk Perusahaan (Parent) Holding Company) didalam pengusahaan bisnis dan managemen anak perusahaan (Subsidiary). Hal ini dapat dikatakan sebagai suatu "breach of duty" dari Induk Perusahaan (Parent/Holding Company) yang semula hanya mengarahkan garisgaris kebijakan perseroan melalui mekanisme RUPS menjadi menentukan kebijakan (policy) anak perusahaan (Subsidiary) dan sekaligus juga melaksanakan proses procurement yang merupakan bagian dari pengurusan perseroan sehari-hari (day to day operation) yang (semestinya) dilaksanakan oleh Direksi anak perusahaan 
(Subsidiary). Sehingga dengan demikian, dapat dikatakan telah terjadi penerobosan batas kemandirian badan hukum baik dari anak perusahaan (Subsidiary) maupun Induk Perusahaan (Parent/Holding Company) dan sebagai konsekuensi hukum atas hal tersebut adalah menjadi terhapusnya tanggung jawab terbatas (limited liability) dari Induk Perusahaan (Parent/Holding Company) sebagai pemegang saham akibat terjadinya penerobosan atas prinsip "Piercing The Corporate Veil" dan Induk Perusahaan (Parent/Holding Company) sebagai pemegang saham akan ikut bertanggung jawab apabila terdapat kerugian dari pihak yang berkepentingan.

\section{Pembatasan Tanggung Jawab dalam pelaksanaan Pengadaan Barang dan/atau Jasa dalam Perjanjian antara Induk Perusahaan (Parent/Holding Company) dengan Anak Perusahaan (Subsidiary).}

Dalam rangka kepentingan dan perkembangan sektor bisnis dan ekonomi, maka pelaksanaan campur tangan induk perusahaan (Parent/Holding Company) didalam pengusahaan bisnis dan managemen anak perusahaan (Subsidiary) untuk bisnis hendaknya diberikan batasan toleransi didalam pelaksanaannya. Sebagaimana dinyatakan oleh Munir Fuady didalam bukunya Hukum Perusahaan dalam paradigma hukum bisnis (berdasarkan Undang-Undang Nomor 40 Tahun 2007) bahwa:

Secara lebih faktual dapat dikatakan bahwa sungguhpun dalam banyak hal hukum harus mentolerir ikut campurnya perusahaan holding kedalam managemen anak perusahaan, tetapi sampai batas-batas tertentu prinsip kemandirian anak perusahaan pun harus tetap dipertahankan. Batas-batas tersebut adalah sejauh nilai-nilai yang harus dipelihara oleh hukum tersebut tidak dilanggar. Misalnya, jika dengan campur tangan induk perusahaan tersebut akan ada pihak-pihak yang dirugikan, katakanlah para kreditor dari anak perusahaan, prinsip kemandirian anak perusahaan sebagai badan hukum semestinya dipertahankan..$^{28}$

Didalam kaitannya dengan sentralisasi kebijakan pelaksanaan procurement dari anak perusahaan (Subsidiary) oleh induk perusahaan (Parent/Holding Company) yang menimbulkan konsekuensi hukum ikut sertanya induk perusahaan (Parent/Holding Company) sebagai pemegang saham untuk turut bertanggung

\footnotetext{
${ }^{28}$ Munir Fuady (n 15).Op.Cit.[132].
} 
jawab apabila terdapat kerugian pada pihak-pihak yang berkepentingan, maka prinsip kemandirian anak perusahaan (Subsidiary) diletakkan dalam tujuan untuk membatasi tanggung jawab yang dibebankan pada masing-masing entitas badan hukum (dalam hal ini adalah anak perusahaan maupun induk perusahaan). Pembatasan tanggung jawab tersebut dapat ditentukan dari keseluruhan proses dan prosedur procurement dimana tanggung jawab induk perusahaan (Parent) Holding Company) adalah melaksanakan keseluruhan prosedur procurement namun tidak termasuk proses penentuan pemenang pengadaan barang dan/atau jasa yang menjadi kewenangan dari anak perusahaan (Subsidiary) sebagai bentuk dari kemandirian pengambilan keputusan. Pembatasan ini dapat diatur dalam suatu perjanjian tersendiri diantara keduanya termasuk didalamnya adalah diaturnya klausula penundukan diri dari anak perusahaan (Subsidiary) terhadap peraturan procurement yang berlaku pada induk perusahaan (Parent/Holding Company) oleh karena mengingat keduanya adalah merupakan badan hukum yang terpisah (separate legal entity) yang mempunyai pengaturannya sendiri-sendiri.

\section{Kesimpulan}

Didalam Undang-Undang Nomor 40 tahun 2007 tentang Perseroan Terbatas tidak menjelaskan secara tegas dan eksplisit mengatur ketentuan khusus mengenai Perseroan Grup (Group Company) maupun Perseroan Holding (Parent/Holding Company). Hukum Perseroan akan tetap memperlakukan Anak Perusahaan (Subsidiary) sebagai suatu entitas hukum yang terpisah (separate legal entity) dari Induk Perusahaan (Parent/Holding Company) yang mempunyai hak dan kewajiban yang mandiri sebagai suatu badan hukum.

Keterlibatan Induk Perusahaan (Parent/Holding Company) ikut menentukan kebijakan non konvensional melalui mekanisme RUPS, yaitu kebijakan sentralisasi procurement dari Anak Perusahaan (Subsidiary) untuk kemudian dilaksanakan oleh Induk Perusahaan (Parent/Holding Company) adalah merupakan bentuk campur tangan Induk Perusahaan (Parent/Holding Company) didalam pengusahaan bisnis dan managemen anak perusahaan (Subsidiary) atau dapat dikatakan sebagai 
"breach of duty" dari Induk Perusahaan (Parent/Holding Company) yang semula hanya mengarahkan garis-garis kebijakan perseroan melalui mekanisme RUPS menjadi menentukan kebijakan (policy) anak perusahaan (Subsidiary) dan sekaligus melaksanakan proses procurement yang merupakan bagian dari pengurusan perseroan sehari-hari (day to day operation) yang (semestinya) dilaksanakan oleh Direksi anak perusahaan (Subsidiary).

Dalam rangka kepentingan dan perkembangan sektor bisnis dan ekonomi, pelaksanaan campur tangan induk perusahaan (Parent/Holding Company) didalam pengusahaan bisnis dan managemen anak perusahaan (Subsidiary) untuk bisnis tersebut diberikan batasan toleransi didalam pelaksanaannya, yaitu dengan tetap menghormati prinsip kemandirian anak perusahaan (Subsidiary). Didalam kaitannya dengan sentralisasi kebijakan pelaksanaan procurement dari anak perusahaan (Subsidiary) oleh induk perusahaan (Parent/Holding Company), maka prinsip kemandirian anak perusahaan (Subsidiary) diletakkan dalam tujuan untuk membatasi tanggung jawab yang dibebankan pada masing-masing entitas badan hukum (dalam hal ini adalah anak perusahaan maupun induk perusahaan). Pembatasan tanggung jawab tersebut yang dapat ditentukan dari keseluruhan proses dan prosedur procurement, dimana tanggung jawab induk perusahaan (Parent) Holding Company) adalah melaksanakan keseluruhan prosedur procurement namun tidak termasuk proses penentuan pemenang procurement yang menjadi kewenangan dari anak perusahaan (Subsidiary) sebagai bagian dari kemandirian pengambilan keputusan. Pembatasan ini dapat diatur dalam suatu perjanjian tersendiri diantara keduanya termasuk didalamnya adalah diaturnya klausula penundukan diri dari anak perusahaan (Subsidiary) terhadap peraturan procurement yang berlaku pada induk perusahaan (Parent/Holding Company) oleh karena mengingat keduanya adalah merupakan badan hukum yang terpisah (separate legal entity) yang mempunyai pengaturannya sendiri-sendiri.

Bahwa dalam mengatasi fenomena perkembangan bisnis dan ekonomi yang mengakibatkan ditemukan beberapa modifikasi-modifikasi terhadap hukum, maka sektor hukum harus tetap dapat berfungsi sebagai palang pintu untuk menciptakan 
nilai-nilai keadilan, kepastian, keteraturan, ketertiban, perlindungan terhadap hak dan kepentingan pihak yang lemah serta beritikad baik. Dalam hal pelaksanaan sentralisasi kebijakan procurement dari Anak Perusahaan (Subsidiary) untuk kemudian dilaksanakan oleh Induk Perusahaan (Parent/Holding Company), maka dalam rangka melaksanakan Tata Kelola Perusahaan Yang Baik (Good Corporate Governance) hendaknya induk perusahaan sebagai pemegang saham membatasi perannya hanya sebatas/semata-semata sebagai pemegang saham dan hanya mengarahkan garis-garis kebijakan perseroan melalui mekanisme RUPS - dalam bentuk arahan pemegang saham, bukan menentukan kebijakan (policy) anak perusahaan (Subsidiary) terlebih lagi ikut melaksanakan proses procurement yang merupakan bagian dari pengurusan perseroan sehari-hari (day to day operation) anak perusahaan (Subsidiary). Namun apabila memang kebijakan ini yang semula menjadi arahan pemegang saham disetujui untuk dilakukan oleh Direksi Anak Perusahaan (Subsidiary), maka pelaksanaan pengadaan barang dan/atau jasa yang dimaksudkan untuk suatu perusahaan grup (Grup Company) hendaknya tidak dilaksanakan oleh induk perusahaan (Parent/Holding Company) melainkan dilaksanakan oleh Anak Perusahaan (Subsidiary) lainnya yang dibentuk khusus dengan bidang usaha melakukan kegiatan usaha procurement. Dengan demikian tanggung jawab apabila terdapat resiko kerugian dari pelaksanaan proses procurement menjadi beban tanggung jawab Anak Perusahaan (Subsidiary) baru yang dibentuk khusus untuk itu.

\section{Daftar Bacaan}

\section{Buku}

Henry Campbell, Black's Law Dictionary (Web Publishing CO 1999).

M. Yahya Harahap, Hukum Perseroan Terbatas (Sinar Grafika 2015).

Marzuki PM, Penelitian Hukum (Kencana Prenada Media Grup 2009).

Munir Fuady, Hukum Perusahaan Dalam Paradigma Hukum Bisnis (Berdasarkan Undang-Undang Nomor 40 Tahun 2007) (PT Citra Aditya Bakti 2008). 
—_, Doktrin-Doktrin Modern Dalam Corporate Law (PT Citra Aditya Bakt 2014).

Robert Prayoko, Doktrin Business Judgement Rule Aplikasinya Dalam Hukum Perusahaan Modern (Graha Ilmu 2015).

Sulistyowati, Aspek Hukum Dan Realita Bisnis Perusahaan Grup Di Indonesia (Erlangga 2010).

Tuti Rastuti, Seluk Beluk Perusahaan Dan Hukum Perusahaan (PT Refika Aditama 2015).

Zaeni Asyhadie dan Budi Sutrisno, Hukum Perusahaan Dan Kepailitan (Erlangga 2012).

\section{Perundang-undangan}

Burgerlijk Wetboek/Kitab Undang-Undang Hukum Perdata.

Wetboek Van Koophandel/Kitab Undang-Undang Hukum Dagang.

Undang-Undang Nomor 1 Tahun 1995 tentang Perseroan Terbatas yang telah dicabut pemberlakuannya dengan Undang-Undang Nomor 40 Tahun 2007 tentang Perseroan Terbatas (Lembaran Negara Tahun 2007 Nomor 106, Tambahan Lembaran Negara Nomor 4756).

HOW TO CITE: Titik Tri Sulistyawati, "Eksistensi Doktrin "Piercing The Corporate Veil" Atas Pelaksanaan Sentralisasi Procurement Anak Perusahaan Oleh Induk Perusahaan' (2018) Vol. 1 No. 1 Notaire. 